\title{
Comparing Citizen Attitudes towards Security and Liberty in the Czech Republic and Slovakia ${ }^{1}$
}

\author{
Zdenka Mansfeldová $^{2}-$ Petra Guasti $^{3}$ - Ivan Petrúšek ${ }^{4}$ - Ol'ga Gyárfášová ${ }^{5}$ \\ The Institute of Sociology, Czech Academy of Sciences, Praha; Goethe \\ University, Frankfurt; Faculty of Social and Economic Sciences, Comenius \\ University in Bratislava
}

\begin{abstract}
Comparing Citizen Attitudes towards Security and Liberty in the Czech Republic and Slovakia. One of the key problems of our time is how much security we want, what price we are willing to pay to feel safe and whether safety leads to satisfaction. Security has a financial and political cost. The article focuses on the relationship between security and privacy from the point of view of a citizen. It examines Czech and Slovak citizen attitudes toward the use of strong prevention security measures in a situation where the government suspects a terrorist attack or security threats in general. We focus on the Czech Republic and Slovakia, two countries that do not have much experience with a severe threat to security, so security is more about pre-emptive measures and general consideration. Data from the two latest ISSP Role of Government modules (IV. and V.) are employed to analyse the degree to which citizens in both countries accept security measures and what are the determinants of their acceptance. We find that a mixture of the low level of trust and a high level of perceived corruption foster sceptical attitudes towards the use of strong security measures. Citizens are less willing to have their personal freedom limited if they do not trust their government. Populists and radical right harness mistrust and fear of immigration to strengthen their issue-ownership on law and order, promising more security but often seeking to limit the freedoms and individual liberties. In this context, the search for the balance between security and liberty has a new urgency and should receive more comparative attention in the future.

Sociológia 2019, Vol. 51 (No. 6: 603-622)

https://doi.org/10.31577/sociologia.2019.51.6.25
\end{abstract}

Key words: Security; liberty; public attitudes; security measures; role of government

\section{Introduction}

In his well-known quote "They who can give up essential liberty to obtain a little temporary safety, deserve neither liberty nor safety" Benjamin Franklin (1904: 58) stressed two features essential to modern democracy - security and

\footnotetext{
1 The research leading to this article has received funding from the Project Changes in the Perception of the Role of Government after the Crisis. The Czech Republic in Comparative Perspective (No. 16-04885S) supported by the Czech Science Foundation. The work of Olga Gyárfášová was supported by the research grant APVV-14-0527, the project Between East and West, Integration or Divergence of Values? Slovakia in Cross-National Comparative Research.

2 Address: PhDr. Zdenka Mansfeldová, CSc., The Institute of Sociology, Czech Academy of Sciences, Jilská 1, 11000 Praha 1, Czech Republic. E-mail: zdenka.mansfeldova@soc.cas.cz

3 Address: PhDr. Petra Guasti, Goethe University Frankfurt, Germany. The Institute of Sociology, Czech Academy of Sciences, Jilská 1, 11000 Praha 1, Czech Republic. E-mail: petraguasti@googlemail.com

4 Address: Mgr. Ivan Petrúšek The Institute of Sociology, Czech Academy of Sciences, Jilská 1, 11000 Praha 1, Czech Republic. E-mail: ivan.petrusek@soc.cas.cz

5 Address: doc. PhDr. Ol'ga Gyárfášová, PhD., Institute of European Studies and International Relations, Faculty of Social and Economic Sciences, Comenius University in Bratislava, Mlynské luhy 4, 82105 Bratislava, Slovak Republic. E-mail: olga.gyarfasova@fses.uniba.sk
} 
liberty. In the era of the growing risk of terrorism, these two features are intimately connected. In technologically advanced capitalism new antagonisms and social conflicts arise around the divide between those affected by risk and those who profit from them (Beck 1992: 46).

In the era of growing inequalities, goods (including happiness and safety) and bads (risks) are not evenly inter- and intra-nationally distributed (Beck 2013, Curran 2013) leading to increasing dissatisfaction with democracy (Han - Chang 2016). The governments in possession of advanced technologies fail to understand that satisfaction/happiness is not merely connected to the absence of fear and a feeling of safety; it is also connected to the absence of infringement on privacy and freedom. As Wagner and Kneip pointed out, citizens faced with potential threats and security risks, often agree with measures restricting their freedom (Wagner - Kneip 2015). However, over time, as the media salience and shock of an attack fade, the support for security measures returns to almost the initial level.

Security has a cost. Financial, concerning security expenditures, but also political - regarding possible constraints on civil liberties. One cannot "have their cake and eat it too". The public uproar against wide-reaching internet surveillance and backlash against perceived government intrusion on citizens' privacy and liberty via CCTV in many Western countries demonstrates that more security often does not make for happier/more satisfied society. On the contrary, some security measures threaten freedoms, directly and indirectly. In summer 2018, this was highlighted in the privacy breach of millions of Facebook user profiles in the Cambridge Analytica case, in which data, collected for research purposes, were used and misused for political manipulations in the elections in the United States and elsewhere in the world. The relation between technology and privacy is becoming more complex, as technologies present legal, economic and political concerns (Finn et al. 2013: 3).

The dilemma of our times, for governments, the media, and individual citizens, is the question of how much safety we desire and at what cost. The answer to this question may differ sharply according to personal experience or the political orientation of the individual actor. This is why security risks and safety are of such a significant concern in today's societies and have brought profound changes to the political order, shaping the perceptions, attitudes, and behavior of people, political leaders and governments (cf. Beck 2002; Inglehart 1997, 2008). Some authors talk about securitization and its transformative effects on political order (see Scheuerman 2016 as well as Cooke Petherbridge 2016; Celikates 2016; Pavone et al. 2016). These concepts usually refer to a situation where a country has experience with terrorist attacks and security measures that are taken in response, reinforcing the oversight role of the state at the expense of citizens' freedom. 
This dilemma is complicated by the development and implementation of new surveillance-oriented technologies. After terrorist attacks in Madrid (2004) and London (2005), the 2008 EU security strategy adopted a more explicit preemptive approach, which relied even more on the implementation of new security technologies which strengthen the conflict between growing surveillance and the protection of individual privacy and civil liberties (Marx 2003). Citizens accept these new technologies in different ways and there are national differences in accepting or rejecting them (Guasti - Mansfeldová 2015; Kazharski - Tabosa 2018).

In this article, we focus on the relationship between security and privacy from the point of view of a citizen. The first part is devoted to the theoretical concept of the relationship between security and liberty, case selection and formulation of research questions. In the second part, we demonstrate this relationship on the example of two particular cases, the Czech Republic and Slovakia, and two-time points. The selection of these time points is determined by the implementation of the ISSP research - the data we use in the article. Authors try to determine what limitations of privacy or civil rights are citizens willing to undertake in the interest of security. We do not examine this issue in relation to real or latent dangers but concerning the role of the state and the functions that citizens expect the state to perform. Furthermore, relationships between attitudes towards security and liberty and other attitudinal and sociodemographic variables are studied.

\section{The theoretical-analytical framework}

In recent years due to the rising occurrence of terrorist attacks, the political importance of security has increased significantly. The terrorist attacks constitute a diffuse security risk, endemic to the late modern societies. The implementation of modern security technologies often addresses diffuse risks, and in urgent cases also by (temporary or permanent) restrictions on freedoms. For example, in the aftermath of the 2015 Paris terrorist attacks, a state of emergency was declared and further extended for almost two years. The competences of the executive branch were strengthened, and a number of measures strengthening the ability of law enforcement to monitor online communication have grown significantly. Some of these measures remain in place in 2018, almost one year after the conclusion of the state of emergency.

These contemporary attempts to control or minimize diffuse risks represent clear evidence of the trade-offs between security and freedoms, especially to privacy $^{6}$. In the name of risk reduction and risk prevention, governments are

\footnotetext{
6 There are several types and definitions of privacy; particular attention is paid to this problem in connection with many new technologies, and most especially new surveillance technologies (see Finn et al. 2013).
} 
extending the powers of law enforcement and security forces, limiting both individual freedoms and democratic scrutiny. The perception of privacy and privacy infringement varies among people. As pointed out by Klitou, to study attitudes to privacy, attention ought to be paid to the current/changing social norms and values, ideological trends, available technologies and infrastructures, political circumstances and the overall state of affairs (Klitou 2014: 14).

The new security/ terrorist threats may increase citizen's tolerance towards introducing security measures (Rykkja et al. 2011: 219-220) and danger can be real or manufactured. Moreover, manufactured danger can have real consequences - as the October 2018 attack on the Pittsburg synagogue known for support for refugees and human rights - indicates. The right to asylum is anchored in international law, and presenting refugees as threat infringes on human rights, of those seeking safety, and ultimately those who support these rights (cf. on the link between security and human rights by Ramcharan 2004).

This means a difficult balance between civil liberties and security in a domestic and international context: between civil rights and individual freedoms on the one hand and the need for stronger internal security and safety on the other. The elected government of any nation has the responsibility to ensure the management of the security sector in line with democratic best practices and the provision of security as a public good.

Governments also bear political responsibility for the activities of the security sector. However, the relation between security and freedom is more complex. The balance between them could be temporal, in a period of crisis (actually existing or latent) part of the population is willing to support more security measures. Didier Bigo points out that freedom and security are not like two equal scales in a balance. "Often they are in hierarchical relations and not an equal one" (Bigo 2006: 39). One has to take into account hierarchy of values community shares. This was demonstrated by Rykkja et al. in their analysis of Norwegian citizens' attitudes towards the use of strong prevention measures in the fight against terrorism (Rykkja et al. 2011).

Michael Saward in the context of the post 9/11 world and the security policy of the UK's government distinguishes two models of protective democracy: majoritarian protective model of democracy (national security is the priority) versus a constitutional protective model of democracy. The constitutional protective model sees rights as inexorable from the people, and not at the disposal of the state. This approach highlights the need for the protection of citizens' rights and liberties against the state itself. The former prioritizes security, the latter liberty, and fundamental rights (Saward 2006: 17-18). We understand the two models as ideal types, not necessarily mutually exclusive binary categories. From the citizen perspective, we interpret the former as a 
higher expectation of protection from the state and security protection priority, and the latter as greater individual responsibility and guaranteeing the civil liberties under any circumstances. Rykkja et al. divides citizens according to their attitudes to these issues to more liberal ones, who prefer civil liberties, and more conservative, preferring security and anti-crime policy (Rykkja et al. 2011). The second group is more willing to delegate to the government the decision on the use of security measures.

Support for civil liberties is connected to large extent with beliefs in democratic institutions and civil liberties. This is a very abstract level, "for ordinary citizens during ordinary times, civil liberties issues are likely to be remote from everyday experience" (Davis - Silver 2004: 28). Let's look at the problem from the point of view of institutions that have the possibility to implement measures restricting civil liberties. Such an institution is primarily the government. However, the willingness to delegate the decision to the government, as institutions emerging from democratic elections, depends heavily on the trust in government. Consequently, we expect that citizens who trust the government more will be more willing to accept government decisions in the case of security measures, and believe the restrictions to personal liberty under security threat will be just temporary and will not be misused. As stated by Davis and Silver in their analysis of public opinion in the context of the terrorist attacks on America "the lower people's trust in government, the less willing they are to trade off civil liberties for security, regardless of their level of threat" (2004: 28).

\section{Case selection}

In our case studies, we focus on countries that do not have much experience with a severe threat to security, and where the public debate and general attention to the dilemma "security versus civil liberties" have been moderate. Unlike many European countries, neither the Czech Republic nor Slovakia experienced a terrorist attack on their soil and, at the time of writing this text, faced no real terrorist threat. In their case, it is more about pre-emptive security ${ }^{7}$ measures and general consideration.

Both countries are parliamentary democracies with direct experience of the authoritarian regime in the recent past, where the state cared for the well-being of citizens and their security, without asking them and often against their will. The communist state ideologically declared/pretended that it cared for the wellbeing and security of its citizens but actually suppressed the liberty and limited the individual security and liberty of anyone who had exceeded the rules of obedience. In Slovakia, this experience lasted a bit longer due to nationalistic

${ }^{7}$ Pre-emptive security emphasizes anticipation of threats and risk management (Pavone et al. 2016). 
and semi-authoritarian backlash in the 1990s which led to an unprecedented polarization of the society and misuse of power against the political opponents. One could, therefore, expect that citizens of both countries will be quite sensitive to state control and interference in their privacy. Nonetheless, the assumed sensitivity may not be that straightforward. It should also depend on general perceptions of the role of the state, i.e., whether people perceive the state as a watchman/guard gendarme or as a caretaker to whom they trust and are willing to support its strong security measures (cf. Rehm 2016). Also, trust to government plays an important role.

In general, most Czechs and Slovaks distrust their governments thus we would expect the acceptance of security measures to be limited. As Figure 1 shows, using data from 28 public opinion surveys collected by the Eurobarometer between 2004 and 2018, governments in both countries had a significantly higher degree of distrust than trust. Over the last 14 years, the Czechs tended to trust their governments less than the Slovaks.

Figure 1: Trust in government in the Czech Republic and Slovakia, 2004 2018

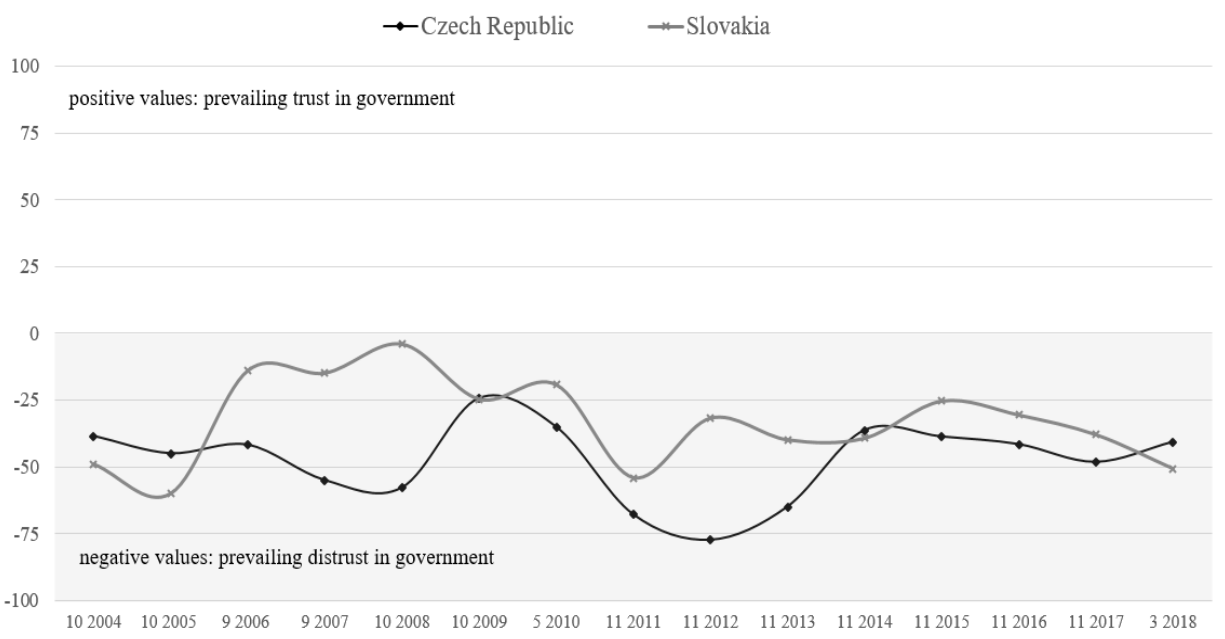

Source: Eurobarometer.

Note: The curves represent the difference between the percentage of respondents trusting the government and the percentage of respondents not trusting the government (hence, the vertical axis is in percentage points). At zero horizontal line, the percentage of respondents who trust the government equals the percentage of respondents who do not trust the government. The graph clearly demonstrates that distrust in government prevails throughout the whole examined period in both counties. 


\section{Research questions}

In our article, we analyze the degree to which citizens in the two countries accept security measures and what are the determinants of their acceptance. Individually, four following research questions are gradually pursued:

1) To what degree do publics in the Czech Republic and Slovakia accept the use of various extraordinary security measures? In particular, we are interested in whether people are willing to accept detaining suspects without trial, tapping telephone conversations and searching people randomly in the street under the assumption that their country's government suspects an immediate terrorist threat.

2) The security situation in Europe changed significantly between 2006 - 2008 and 2016 (i.e. the data points for which we analyse the ISSP data). In particular, two major terrorist attacks happened in Europe immediately before 2016 fieldwork periods (i.e., Brussels bombings in March and Nice truck attack in July). Moreover, 2016 was a year when the European migrant crisis was still getting significant media coverage (and populist politicians in both countries were coining the migrant crisis with increased terrorism threat). Are there in view of the above-mentioned situation any changes in public attitudes towards government's rights between the two studied time points?

3) To what extent do socio-demographic factors and attitudinal variables correlate with citizens' support for the extraordinary security measures (by which individual privacy and liberty are breached) to cope with the threat of an imminent terrorist attack? Furthermore, we are interested in which variables have the most significant explanatory power and whether these variables explain the underlying attitudes consistently in time.

4) What is the role of trust in government with respect to explaining individual attitudes towards increased government powers?

\section{Data, variables, descriptive statistics and analytical strategy}

This article uses four datasets which were collected as part of the national implementation of the International Social Survey Programme (ISSP) Role of Government modules in the Czech Republic and Slovakia. The first two datasets were part of the fourth round of the Role of Government module. The Czech data from this module was collected in October/November $2006(\mathrm{n}=$ 1201) and Slovak data was collected in October $2008(\mathrm{n}=1138)$. The second pair of datasets was part of the fifth round of Role of Government. The Czech data from the latest module were fielded between May and July $2016(\mathrm{n}=$ 1400), and Slovak data was fielded in October/November $2016(\mathrm{n}=1150)$. Unless otherwise stated, missing data in all presented analyses were dealt with 
using the listwise deletion (since the proportion of missing data on individual variables was usually well below $5 \%$ ).

Dependent variable. The article studies people's attitudes towards extraordinary governmental security measures under the supposed terrorist threat. Although the three corresponding questionnaire items employed to tap these attitudes explicitly mention the hypothetical threat of a terrorist attack in the country ("Suppose the government suspected that a terrorist act was about to happen"), the reference to the trade-off between security and liberty is only implicit. In other words, the realization that increased governmental rights inevitably reduce individual rights and liberties is left to the respondents' discretion. Table 1 plots relative frequencies of valid answers to the three respective questionnaire items. The original four-level scale $(1-$ definitely should have right; 2 - probably should have right; 3 - probably should not have right; 4 - definitely should not have right) was dichotomized for this table. In general, Czechs accept the potential use of strong prevention measures more widely than Slovaks. Furthermore, this difference between Czechs and Slovaks increased over time - between 2006 (2008 for Slovakia) and 2016 the Czech attitudes remained stable, while Slovak support for all three measures decreased significantly (by 16, 12, and 7 percentage points, respectively).

Table 1: Attitudes towards government security measures under the terrorist threat (column percentages)

\begin{tabular}{lcccc}
\hline & \multicolumn{2}{c}{ Czech Republic } & \multicolumn{2}{c}{ Slovakia } \\
\hline & $\mathbf{2 0 0 6}$ & $\mathbf{2 0 1 6}$ & $\mathbf{2 0 0 8}$ & $\mathbf{2 0 1 6}$ \\
\cline { 2 - 4 } $\begin{array}{l}\text { A.) to detain people for as long as they want without } \\
\text { Definitely/probably should have right }\end{array}$ & 64 & 65 & 55 & 39 \\
Probably/definitely should not have right & 36 & 35 & 45 & 61 \\
B.) to tap people's telephone conversations & & & 51 & 39 \\
Definitely/probably should have right & 65 & 64 & 49 & 61 \\
Probably/definitely should not have right & 35 & 36 & & 38 \\
C.) to stop and search people in the street at random & & & 45 \\
Definitely/probably should have right & 56 & 57 & 55 & 62 \\
Probably/definitely should not have right & 44 & 43 & & \\
\hline
\end{tabular}

Source: ISSP Role of Government (IV. and V.)

Answers to all three items are highly positively correlated in both countries and both ISSP modules (the lowest value from 12 resulting bivariate correlations between the three items is 0,5 ; whereas the highest correlation crosses 0,8 ). This strongly suggests that the three items reliably measure an underlying latent construct. Consequently, the summary measure of attitudes 
toward counter-terrorism measures was constructed. This aggregate index was created from three items as the arithmetic mean of the valid answers (e.g., when a respondent provided only one valid answer, this single answer is the value of the index). Consequently, the created index has the same range of values as the original items: 1 denotes maximum support for a repressive activity of state authorities, and 4 denotes maximum resistance against the use of repressive measures (despite the assumed terrorist threat). The descriptive statistics of the index are summarized in Table 2.

Table 2: Index of attitudes towards government rights (under terrorism threat)

\begin{tabular}{lcccc}
\hline & CR: 2006 & CR: 2016 & SR: 2008 & SR: 2016 \\
\hline Cronbach's alpha of index reliability & $\mathbf{0 , 8}$ & $\mathbf{0 , 8 7}$ & $\mathbf{0 , 8 7}$ & $\mathbf{0 , 9 1}$ \\
Index: the mean & 2,31 & 2,30 & 2,53 & 2,83 \\
Index: standard deviation & 0,86 & 0,89 & 0,85 & 0,92 \\
Index: 95\% conf. interval for the mean & $2,26-2,36$ & $2,26-2,35$ & $2,48-2,59$ & $2,77-2,88$ \\
\hline
\end{tabular}

Source: ISSP Role of Government (IV. and V.)

In line with the frequency analysis of the index-constituting items (Table 1), the index shows that there is no difference in the Czech Republic between the two-time points. In Slovakia, there has been a significant decline in support of state authorities to use the abovementioned repressive instruments. At the same time, the Slovaks are significantly more against the use of strong prevention security measures than the Czechs at both time points (since the corresponding confidence intervals at the bottom line of Table 2 do not overlap).

Explanatory and control variables. The article studies the relationships between attitudes toward government rights and several explanatory variables utilized in previous quantitative studies or discussed in the theory section. This subsection briefly describes the operationalization and coding of these explanatory variables. Descriptive statistics of explanatory variables are summarised in Table 3.

Sociodemographic variables are coded as follows. Age is measured in years, and its observed values range between 18 years (observed in all four analyzed ISSP datasets) and around 90 years (depending on a particular ISSP dataset). Educational attainment is measured as a binary variable where university education (bachelor's, master's and doctoral degrees coded as 1) is contrasted against all remaining educational attainments (coded as 0 ). Males constitute a reference category on the gender variable (i.e., females are coded as 1).

The article also studies the effects of several attitudinal variables which are all measured using ordinal scales. Interest in politics is an ordinal variable ranging from not at all interested (coded as 0 ) to very interested (coded as 3). 
Trust in public servants measures level of agreement with the statement "Most public servants can be trusted to do what is best for the country," and its values range from strongly agree (1) to strongly disagree (5). This variable is used as a proxy measure for the trust in government (which is not available in the analyzed ISSP data sets). Furthermore, the article also studies the effect of respondents' evaluation of the government success rate in dealing with threats to the respective country's security. The values of this indicator range between 1 (very successful) and 5 (very unsuccessful).

Along with the discussed security measures under terrorist threat, the ISSP Role of Government fifth round (2016) also contained additional questions which probed respondents whether "government should have the right to take certain measures in the name of national security." In particular, respondents were asked whether their government should have the right to "collect information about anyone living in (the Czech Republic/Slovakia) without their knowledge" and "collect information about anyone living in other countries without their knowledge." These two general items were asked before the three index-constituting items and not referred to the terrorist threat. In both countries, answers to these two questions were very strongly correlated $(0,77$ in the Czech Republic and 0,87 in Slovakia) and therefore an index of attitudes towards undercover government collection of private information was created (values of this index range from 1 to 4 ). As the bottom row of Table 3 suggests, Czechs and Slovaks hold predominantly negative attitudes towards government gathering information on people (these negative attitudes are significantly stronger in Slovakia, where the average value of the index is 3,16). However, when the terrorist threat is explicitly mentioned in the question wording (as justification for detaining people without trial on an unlimited time basis or randomly stopping and searching people in the street), respondents in both counties are more willing to extend repressive government rights. In other words, the threat of terrorism induces respondents to tolerate harsher violations of private/civil rights.

Having described variable coding, the next section analyses bivariate relationships between attitudes toward government rights under terrorist threat and a list of several explanatory/control variables. With binary explanatory variables, an independent samples t-test is employed to compare the mean value of the index of attitudes towards government rights between a pair of groups. With ordinary explanatory variables, Spearman correlation coefficient is used (Pearson correlation coefficient is computed to study the relationship between the index and age). The subsequent section deploys multivariate linear regression modelling to simultaneously control the effects of several explanatory variables on attitudes towards government rights. 
Table 3: Descriptive statistics of explanatory variables: Mean (standard deviation)

\begin{tabular}{lcccc}
\hline \multirow{2}{*}{ Variable } & \multicolumn{2}{c}{ Czech Republic } & \multicolumn{2}{c}{ Slovakia } \\
\cline { 2 - 5 } age & $\mathbf{2 0 0 6}$ & $\mathbf{2 0 1 6}$ & $\mathbf{2 0 0 8}$ & $\mathbf{2 0 1 6}$ \\
educational attainment (tertiary) & $49,4(17,4)$ & $48,4(17,1)$ & $46,8(16,1)$ & $51,0(16,7)$ \\
gender (female) & $0,11(0,31)$ & $0,16(0,37)$ & $0,14(0,34)$ & $0,16(0,36)$ \\
interest in politics & $0,58(0,49)$ & $0,52(0,50)$ & $0,61(0,49)$ & $0,57(0,50)$ \\
trust in public servants & $1,03(0,95)$ & $0,79(0,87)$ & $1,08(0,80)$ & $0,68(0,80)$ \\
government success in dealing with security threats & $2,65(0,93)$ & $2,59(0,85)$ & $2,58(0,96)$ & $\mathrm{NA}$ \\
index of collection of private information & $\mathrm{NA}$ & $2,82(0,87)$ & $\mathrm{NA}$ & $3,16(0,83)$ \\
\hline
\end{tabular}

Source: ISSP Role of Government (IV. and V.)

Note: The mean of a binary variable (i.e. educational attainment and gender) represents a proportion of respondents belonging to the group coded as 1 (having tertiary education and being female). For example, 0,16 in Slovakia 2016 means that the dataset contains $16 \%$ of respondents with tertiary education and 0,57 means that $57 \%$ of respondents in the 2016 Slovak data are female.

$\mathrm{NA}=$ variable is not available in the data.

\section{Bivariate relationships}

In general, the bivariate relationships between attitudes towards government rights and the set of explanatory variables are weak. As suggested by Table 4, these relationships are not always statistically significant across four analyzed country-year dataset combinations. The only case of inconsistent relationship is with gender where the statistically significant difference between genders moves in the opposite direction between the two analyzed countries. The following paragraphs briefly summarize the bivariate relationships presented in Table 4.

Age. Older people tend to be slightly more inclined to support increased rights for the police than younger citizens. This very weak tendency is present in both countries in round 4 of the ISSP Role of Government module and is in line with the expectation that younger individuals are more supportive of liberal democratic values than older people (Davis - Silver 2004). Another possible explanation of this weak relationship is greater reliance on state institutions and the perception of a state as a caretaker among the elderly (which may also be partially driven by socialization under socialism).

Education. Tertiary education is quite strongly associated with sceptical attitudes towards expanded police rights. People with a university degree were on average significantly less supportive of increased anti-terrorism government rights in 2006 (2008 in the Slovak case). This finding is consistent with the expectation that highly educated citizens are both more critical (i.e., aware of 
the imminent trade-off between security and liberty) and (ceteris paribus) more inclined to be closer to the liberal pole of the trade-off continuum. Furthermore, people with lower educational attainment tend to have a higher perceived threat of a terrorist attack occurring and thus be more willing to accept expanded police rights at the expense of individual liberties (Huddy et al. 2005).

Table 4: Bivariate relationships between attitudes towards government rights and explanatory variables

\begin{tabular}{|c|c|c|c|c|}
\hline \multirow[b]{2}{*}{ Variable } & \multicolumn{2}{|c|}{ Czech Republic } & \multicolumn{2}{|c|}{ Slovakia } \\
\hline & 2006 & 2016 & 2008 & 2016 \\
\hline age & $r=-0,09^{* *}$ & $r=-0,03$ & $r=-0,07^{*}$ & $r=0,03$ \\
\hline $\begin{array}{l}\text { education } \\
\text { (tertiary) }\end{array}$ & $\overline{\mathbf{x}}_{\text {tert }}-\overline{\mathbf{x}}_{\text {ref }}=\mathbf{0 , 2 1 ^ { * * }}$ & $\overline{\mathrm{X}}_{\text {tertiary }}-\overline{\mathrm{X}}_{\mathrm{ref}}=-0,11$ & $\overline{\mathbf{x}}_{\text {tertiary }}-\overline{\mathbf{x}}_{\text {ref }}=\mathbf{0 , 1 5 ^ { * }}$ & $\overline{\mathrm{X}}_{\text {tertiary }}-\overline{\mathrm{X}}_{\text {ref }}=-0,13$ \\
\hline gender (female) & $\overline{\mathbf{x}}_{\mathrm{fem} .}-\overline{\mathbf{x}}_{\text {male }}=-\mathbf{0}, \mathbf{1}^{*}$ & $\overline{\mathrm{X}}_{\mathrm{fem} .}-\overline{\mathrm{x}}_{\text {male }}=-0,03$ & $\overline{\mathbf{x}}_{\text {fem. }}-\overline{\mathbf{x}}_{\text {male }}=\mathbf{0 , 1 2 ^ { * }}$ & $\overline{\mathrm{x}}_{\mathrm{fem} .}-\overline{\mathrm{x}}_{\mathrm{male}}=0,06$ \\
\hline interest in politics & $r_{s}=-0,02$ & $r_{\mathrm{s}}=-\mathbf{0 , 1} 4^{* * *}$ & $r_{\mathrm{s}}=0,02$ & $\mathbf{r}_{\mathrm{s}}=-\mathbf{0 , 1 1 ^ { * * * }}$ \\
\hline $\begin{array}{l}\text { trust in public } \\
\text { servants }\end{array}$ & $\mathbf{r}_{\mathrm{s}}=\mathbf{0 , 1 2 ^ { * * * }}$ & $r_{s}=-0,01$ & $r_{s}=0,06$ & $r_{\mathrm{s}}=0,19^{* * *}$ \\
\hline $\begin{array}{l}\text { gov. success with } \\
\text { security threats }\end{array}$ & $\mathbf{r}_{\mathrm{s}}=0,10^{* *}$ & $\mathrm{r}_{\mathrm{s}}=0,03$ & $\mathbf{r}_{\mathrm{s}}=0,10^{* *}$ & NA \\
\hline $\begin{array}{l}\text { index of collection } \\
\text { of private inf. }\end{array}$ & NA & $r_{\mathrm{s}}=0,39^{* * *}$ & NA & $\mathbf{r}_{\mathrm{s}}=0,47^{* * *}$ \\
\hline
\end{tabular}

Source: ISSP Role of Government (IV. and V.)

Notes: $* \mathrm{p}<0,05 * * ; \mathrm{p}<0,01 ; * * * \mathrm{p}<0,001 ; \mathrm{NA}=$ variable is not available in the data

$\mathrm{r}=$ Pearson correlation coefficient; $\mathrm{r}_{\mathrm{s}}=$ Spearman's rank correlation coefficient; $\overline{\mathrm{x}}_{\text {tert }}-\overline{\mathrm{x}}_{\text {ref }}=$ difference between the arithmetic means computed within two groups (significance of the difference is based on the results of the independent samples t-test)

Gender. One of the stable findings of risk perception studies is the significant difference between men and women in risk perception and support for security measures. Women tend to exhibit a higher level of apprehension of both threats - the perceived personal and national - than men, even though they are not more likely to be affected by the threat (Huddy et al. 2002; Huddy et al. 2005). Nonetheless, the data analyzed in this paper provide evidence for this claim only in the case of the Czech Republic. Women in Slovakia are, on the other hand, more often against the extending police rights under the terrorist threat than men.

Interest in politics. The significant negative correlation between interest in politics and the expansion of security measures is present in both countries (only in 2016, though). This relationship suggests that people not at all interested in politics tend to be more against the use of repressive measures by the police than people with higher levels of political interest (who on the other hand, tend to support these repressive measures more). If one accepts the 
conceptualization employed by Rykkja, Lægreid and Fimreite (2011) that interest in politics represents a constitutive part of political efficacy, the negative relationship between political efficacy and the index may suggest the internal belief that government authorities will not pursue strong measures unless absolutely necessary (i.e., people with a high level of political efficacy are likely to have this attitude). The presented data are broadly in line with this expectation about the relationship between political efficacy and attitude towards increased security measures in both countries (in 2016, when the relationship is statistically significant). Nevertheless, since interest in politics may only function as a rough proxy for political efficacy, this explanation extrapolates beyond what the analyzed data can unambiguously demonstrate.

Trust in public servants. Trust in public servants (i.e., officials who execute decisions and implement policies agreed upon by the country government) is employed here as a proxy measure of trust in government. In both analyzed countries, trust in public servants is positively correlated with the attitudes towards expanded government rights (although, in the Czech Republic, the correlation is statistically significant only in 2006 and in Slovakia, the relationship is significant only in 2016). The variable coding implies that people with low levels of trust in public servants are less willing to trade off civil liberties for security. Put differently, people not trusting that most public servants do what is best for the country also tend to be against the expansion of security rights of the police. High level of trust, on the other hand, is associated with positive attitudes towards expanded policing rights under the terrorist threat.

Government success in dealing with security threats. This variable, which was not part of the 2016 Slovak data, represents another measure of confidence in government. Table 4 reports a weak positive relationship between attitudes towards government rights and their success in dealing with security threats. In other words, there is a weak tendency to oppose the expansion of government rights when one believes the government is not successful in facing security threats. It is possible that people sceptical of government efficiency in dealing with threats will also be reluctant to grant extended government authority under terrorist threat.

Collection of private information. Regrettably, this variable is only available in the fifth round of the Role of Government module fielded in 2016. It is quite strongly correlated with the index in both countries, suggesting that respondents generally willing to trade off liberty for security also tend to support the expansion of police rights under the terrorist threat. In other words, these results suggest an underlying preference of the respondent concerning the 
implied trade-off. Some citizens in the Czech Republic and Slovakia prefer security regardless of the circumstances while other citizens tend to prefer civil liberties. A certain proportion of the respective populations tend to agree with the expansion of police rights only under serious security threat (such as a terrorist attack).

\section{Modelling attitudes towards government rights}

Table 5 reports two OLS regression models of attitudes towards government rights that were estimated separately for each country-year combination. The first model includes only sociodemographic variables (age, education, and gender) as predictors. This model studies how position in the social structure is associated with attitudes towards increased government rights under terrorist threat. The second model adds a set of attitudinal explanatory variables to the regression equation. The aim is to assess the improvement of the explanatory power of the model by adding a group of mostly attitudinal correlates of the outcome variable. Presented regression models control the effects of several explanatory variables on the outcome at the same time, thus providing a more robust insight into attitudes towards increased government rights under the terrorist threat. The potential shortcoming of the second model is possible endogeneity of some of the included predictors (in particular, with respect to the index of a collection of the private information).

The sociodemographic model has only very limited explanatory power since the adjusted index of determination $\left(\mathrm{R}^{2}\right)$ reaches a maximum of $2 \%$. In 2016, the sociodemographic model completely fails to account for the variability in the attitudes towards increased government rights. This conclusion is also suggested by the omnibus F test of the model (where the null hypothesis is not rejected). Consequently, knowing the position of an individual in the social structure in 2016 provides no hint about one's standing on the implied trade-off between security and liberty. These rather dismal findings are in line with the bivariate relationships presented in Table 4. Models from the fourth round of ISSP (i.e., 2006, resp. 2008 in Slovakia) appear to be more promising. Controlling for other variables, the effect of gender in the Czech Republic is not significant at the 0,05 significance level. Being female in Slovakia in 2008 is quite strongly associated with negative attitudes towards granting more restrictive rights to government authorities. The effect of tertiary education is, ceteris paribus, strongly associated with negative attitudes (when compared to the reference group) in both countries. All else being equal, model one suggests that having tertiary education is associated with the expected value of the index higher by 0,2 (which represents approximately $7 \%$ of the range of the dependent variable). 
Table 5. Linear regression models (unstandardized regression coefficients)

\begin{tabular}{|c|c|c|c|c|c|c|c|c|}
\hline \multirow[b]{3}{*}{ Variable } & \multicolumn{4}{|c|}{ Czech Republic } & \multicolumn{4}{|c|}{ Slovakia } \\
\hline & \multicolumn{2}{|c|}{2006} & \multicolumn{2}{|c|}{2016} & \multicolumn{2}{|c|}{2008} & \multicolumn{2}{|c|}{2016} \\
\hline & Model 1 & Model 2 & Model 1 & Model 2 & Model 1 & Model 2 & Model 1 & Model 2 \\
\hline age & $-0,004^{* *}$ & $-0,004^{*}$ & $-0,002$ & $-0,001$ & $-0,004^{*}$ & $-0,004^{*}$ & 0,001 & 0,001 \\
\hline $\begin{array}{l}\text { education } \\
\text { (tertiary) }\end{array}$ & $0,214^{* *}$ & $0,289^{* * *}$ & $-0,126$ & $-0,114$ & $0,163^{*}$ & $0,166^{*}$ & $-0,123$ & $-0,129$ \\
\hline gender (female) & $-0,094$ & $-0,104$ & $-0,029$ & $-0,046$ & $0,13^{*}$ & $0,137^{*}$ & 0,058 & 0,026 \\
\hline $\begin{array}{l}\text { interest in } \\
\text { politics }\end{array}$ & & $-0,042$ & & $-0,081^{* *}$ & & 0,065 & & $-0,073^{*}$ \\
\hline $\begin{array}{l}\text { trust in public } \\
\text { servants }\end{array}$ & & $0,136{ }^{* * *}$ & & $-0,039$ & & 0,014 & & $0,077^{* *}$ \\
\hline $\begin{array}{l}\text { gov. success } \\
\text { with security } \\
\text { threats }\end{array}$ & & $0,087^{* *}$ & & 0,011 & & $0,099^{* *}$ & NA & NA \\
\hline $\begin{array}{l}\text { index of a } \\
\text { collection of } \\
\text { private inf. }\end{array}$ & NA & NA & & $0,417^{* * *}$ & NA & NA & & $0,481^{* * *}$ \\
\hline intercept & $2,553^{* * *}$ & $1,841^{* * *}$ & $2,438^{* * *}$ & $1,386^{* * *}$ & $2,597^{* * *}$ & $2,236^{* * * *}$ & $2,768^{* * * *}$ & $1,029^{* * * *}$ \\
\hline $\mathrm{R}^{2}$ adjusted & 0,02 & 0,05 & 0 & 0,18 & 0,01 & 0,02 & 0 & 0,22 \\
\hline $\mathrm{N}$ & 1159 & 1073 & 1323 & 1159 & 1031 & 915 & 1085 & 982 \\
\hline
\end{tabular}

Source: ISSP Role of Government (IV. and V.)

Notes: $* \mathrm{p}<0,05 * * ; \mathrm{p}<0,01 ; * * * \mathrm{p}<0,001, \mathrm{NA}=$ variable is not available in the data

The dependent variable ranges between 1 (i.e. maximum support to a repressive activity of state authorities) and 4 (i.e. maximum resistance against the use of repressive measures under terrorism threat).

Including attitudinal variables in the model is associated with significant improvements in the model overall fit to the data. This is predominantly evident in 2016 where the interest in politics and especially the general attitude towards the undercover collection of private information moderate these substantive gains ${ }^{8}$. In particular, a one-point increase in the corresponding index of a collection of private information is ceteris paribus associated with the expected increase of the negative attitudes towards government rights by approximately 0,42 in the Czech Republic and 0,48 in Slovakia (which represents approximately $16 \%$ of the range of the dependent variable). Controlling for other variables in the model, the higher interest in politics is still associated with more positive attitudes towards implementing repressive police measures under terrorist threat. The weak tendency to oppose the expansion of government rights when one questions government success in facing security threats is still present upon controlling for other explanatory

\footnotetext{
${ }^{8}$ On the other hand, the presented model 2 does an insufficient job in explaining attitudes towards increased government rights in Slovakia 2008. This model only accounts for $2 \%$ of the variation in the index of attitudes towards government rights.
} 
variables in the model. Analogically, low trust in public servants is ceteris paribus associated with the expected opposition to increased government rights. The effects of the three studied sociodemographic variables in model 2 are the same as in model 1.

One particular variable, whose complete unavailability in the analyzed ISSP datasets may result in the omitted variable bias, is the individual perception of the extent of the terrorist threat. Davis and Silver (2004) in the American context demonstrate that greater people's perception of terrorist threat, the higher their support for increased government rights to cope with the terrorist threat. Although neither Czech Republic nor Slovakia has direct experience with a terrorist attack on their soil, this omitted variable may still lead to a substantial bias of regression coefficients estimates (and lower fit of the models to the data). In other words, despite the probable lower average perceived threat of terrorist attack in former Czechoslovakia; this omitted variable is still likely to be associated with the willingness to trade-off civil liberties for increased security.

\section{Concluding discussion}

The aim of this paper was two-fold. First, by measuring citizens' acceptance of the use of prevention measures by the state and police, the paper analyzed the degree to which the limitation of the citizens' liberty is perceived as legitimate under the terrorist threat. Second, it described and attempted to explain the variation in the attitudes toward these measures in the Czech Republic and Slovakia. The findings contribute to a broader discussion on balance between civil liberties and security and about the role of different perception of risk and threat play when the trust to government is low.

The results show higher acceptance of security measures in the Czech Republic than in Slovakia. The Slovaks are significantly more against the use of strong prevention security measures than Czechs. Over time, there is no difference in the Czech case, but in Slovakia, the refusal to use of strong prevention security measures intensified. Using Saward (2006) and Rykkja et al. (2011), Czechs seem to be somewhat conservative, supporting a majoritarian protective model of democracy, while Slovaks, appear to be more liberal, better befitting the constitutional protection model.

The expectation that increased government confidence would be associated with greater acceptance of preventive security measures or less reluctance to their use has not been confirmed unambiguously, especially in the case of Slovakia, where the association was not present in 2008 and was only weak in 2016. Here an important caveat limits our ability to interpret our findings decidedly. We used trust in public servants as a proxy for trust in government. Ideally, additional measures as the government's success in dealing with 
security threats or individual political orientation should be part of the analysis. Unfortunately, these variables were not available in all four analyzed data sets.

Overall, the presented analyses show that the relationship between attitudes toward government rights and the set of explanatory variables is weak. The sociodemographic model (including age, education, gender) has only very limited explanatory power, especially in 2016. In the first period (2006/2008), the attitudes towards the use of strong prevention security measures (acceptance/rejection) are related (even if weakly) to standard explanatory variables such as age, education, gender. Younger respondents are less supportive of repressive security measures than elder people. The sociodemographic model has, in general, a limited explanatory power, and severely fails to explain the variability in the attitudes toward government rights. Over time, the standard socioeconomic variables are receding into the background, and the attitudinal variables seem to grow in importance.

The corruption perception undermines citizens' confidence in the state, which further leads to the rejection of the state to provide security, by legitimate use of violence to protect its citizens. The mixture of the low level of trust and a high level of perceived corruption foster sceptical attitudes towards the use of strong security measures. Citizens do not trust the state they perceive to be corrupt. The case of recent corruption scandals in Slovakia exemplifies this. For a long time, the Slovak government did not tackle corruption, and the performance of democratic institutions was worsening (cf. Bertelsmann 2018). The investigation of the murder of a journalist Jan Kuciak and his fiancé (2018) lay bare the connection between politicians, police, and the criminal underworld. It supposedly led to further vigilance toward measures that could limit personal freedom. People are less willing to have their personal freedom limited if they cannot trust their (corrupt) government.

These findings hold for both time points, correspond with other ISSP survey findings, and are consistent with other studies within the region. Slovakia together with Hungary and Poland, belong to a group of countries where the perception of corruption among politicians is high above average (Bahna and Zagrapan 2017). The continuing critical perception of political corruption is paired with very high mistrust towards the police. Also, the judiciary may help explain why Slovak support for all three measures decreased between 2008 and 2016 (Table 1).

In the Czech Republic, in the absence of a large-scale scandal involving police, these attitudes are less strong. The findings indicate that despite strong inclination of the Slovak public to the caretaking state in social area (Džambazovič 2011) when it comes to security and civil rights, Slovaks are less willing to accept expanded police rights than the Czechs. This "national pattern" did not change over time even though the contextual situation of how 
the possible threats might be perceived and how massively are they securitized have changed dramatically.

Both the Czech Republic and Slovakia are stable democracies, yet in both countries, the trust in governments and public servants is generally very low. In the first period, only one in ten people expressed the opinion that public servants can be trusted. In the second period (2016), confidence in the government and public servants improved somewhat in both countries; however, we can observe less stability of the government, fears of the consequences of the migration crisis and rise of populism. The rise of populism is relevant here, as the populist parties often campaign on 'law and order' issues. The populist rhetoric securitizes migration and manufactures fear.

Unhinged rhetoric can have real consequences. In January 2019, a 71-year old retired electrician J.B., who became radicalized on social media was sentenced to four years in prison on domestic terrorism charges in the Czech Republic. In summer 2017 he cut trees on the railroad trucks - causing the derailment of a train, and distributed fake pamphlets, which in purposefully broken Czech blamed the accident on Muslim refugees. In his defense, he claimed he wanted to protect the country from the 'Muslim invasion' and to 'wake-up the Czechs to the danger of refugees'.

In the Czech Republic and Slovakia populists and radical right harness the fear of immigration to strengthen their anti-establishment rhetoric and issueownership on law and order issues. The populist rhetoric paints freedom and personal liberty as a price citizen must pay for security. The fear of immigration contributes to the rise of populist and radical right forces, which promise more security but often seek to limit the freedoms and individual liberties. In this context, the search for the balance between security and liberty has a new urgency and should receive more comparative attention in the future.

Zdenka Mansfeldová is a senior research fellow and head of the Department of Political Sociology at the Institute of Sociology, Czech Academy of Sciences. In her research, she focuses on the functioning of modern democracies and their institutions, political and non-political forms of interest representation.

Petra Guasti is an Interim Professor of Political Science at the Goethe University Frankfurt (Germany) and research fellow at the Institute of Sociology, Czech Academy of Sciences. Her research focus is on democracy, representation, and civil society, with particular focus on Central and Eastern Europe.

Ivan Petrúšek is a doctoral candidate and a junior researcher at the Institute of Sociology, Czech Academy of Sciences. In his research, he is primarily interested in attitudes towards welfare state and political participation in post-communist countries. 
Ol'ga Gyárfášová is associate professor and senior researcher at the Institute of European Studies and International Relations, Faculty of Social and Economic Sciences, Comenius University in Bratislava. In her research she focuses on European integration, electoral studies and political culture. She is author and coauthor of dozens of expert studies. She is also national coordinator of the European Election Studies (EES) and the world-wide project Comparative Studies of Electoral Systems (CSES).

\section{REFERENCES}

BAHNA, M. - ZAGRAPAN, J., 2017: Názory občanov na korupciu a ich osobná skúsenost'. Tlačová konferencia v rámci projektu APVV-14-0527. http://www.sociologia.sav.sk/cms/uploaded/2543_attach_Bahna_Zagrapan_korupci a.pdf

BECK, U., 1992: Toward New Modernity. London: Sage.

BECK, U., 2002: The Terrorist Threat. World Risk Society Revisited. In: Theory, Culture \& Society 19, No. 4, pp. 39-55.

BECK, U., 2013: Why 'Class' is too Soft a Category to Capture the Explosiveness of Social Inequality at the Beginning of the Twenty-First Century. The British Journal of Sociology 64, No. 1, pp. 63-74.

BERTELSMANN STIFTUNG, BTI 2018: Country Report - Slovakia. Gütersloh: Bertelsmann Stiftung, 2018.

BIGO, D., 2006: Liberty, whose Liberty? The Hague Programme and the Conception of Freedom. In: Balzacq, Thierry, Sergis Carrera (eds.): Security versus Freedom? A Challenge for Europe's Future. Aldershot and Burlington: Ashgate, pp. 35-59.

CELIKATES, R., 2016: Democratizing Civil Disobedience. Philosophy \& Social Criticism 42, No. 10, pp. 982-994.

COOKE, M. - PETHERBRIDGE, D., 2016: Civil Disobedience and Conscientious Objection. Philosophy \& Social Criticism 42, No. 10, pp. 953-957.

CURRAN, D., 2013: Risk Society and the Distribution of Bads: Theorizing Class in the Risk Society. British Journal of Sociology 64, No. 1, pp. 44-62.

DAVIS, D. W. - SILVER, B. D., 2004: Civil Liberties vs. Security: Public Opinion in the Context of the Terrorist Attack on America. American Journal of Political Science 48, No. 1, pp. 28-46.

DŽAMBAZOVIČ, R., 2011: Legitimita sociálneho štátu: názory verejnosti na princípy a fungovanie sociálnej politiky. In: Gerbery, D. (Ed.): Potrebujeme sociálny štát? Úvahy (nielen) o verejnej politike. Bratislava: FES, pp. 131-161.

FINN, R. L. - WRIGHT, D. - FRIEDEWALD, M., 2013: Seven Types of Privacy, pp. 3-32 in Gutwirth, Serge, Ronald Leenes, Paul de Hert, Yves Poullet (eds.), European Data Protection: Coming of Age. Springer Science and Business Media Dordrecht.

FRANKLIN, B., 1904, The Works of Benjamin Franklin: Including the Private as Well as the Official and Scientific Correspondence, Together with the Unmutilated and Correct Version of the Autobiography (compiled and edited by John Bigelow). New York: G.P. Putnam's Sons. 
GUASTI, P. - MANSFELDOVÁ, Z., 2015: Comparative Discourse Analysis of the Security-Privacy Dilemma: Salience of Security Issues in Printed Media. Ciencia e technical Vitivinicola, 30, pp. 127-156.

HAN, S. M. - CHANG, E. C., 2016: Economic Inequality, Winner-Loser Gap, and Satisfaction with Democracy. Electoral Studies 44, pp. 85-97.

HUDDY, L. - FELDMAN, S. - CAPELOS, T. - PROVOST, C., 2002: The Consequences of Terrorism: Disentangling the Effects of Personal and National Threat. Political Psychology 23, No. 3, pp. 485-509.

HUDDY, L. - FELDMAN, S. - TABER, Ch. - LAHAV, G., 2005: The threat, Anxiety, and Support of Antiterrorism Policies. American Journal of Political Science 19, No. 3, pp. 593-608.

INGLEHART, R., 1997: Modernization and Postmodernization: Cultural, Economic and Political Change in 43 Societies. Princeton: Princeton University Press.

INGLEHART, R. F., 2008: Changing Values among Western Publics from 1970 to 2006. West European Politics 31, No. 1-2, pp. 130-146.

KAZHARSKI, A. - TABOSA, C., 2018: New Patterns of Securitization in Central and Eastern Europe. In: R. Q. Turcsányi \& M. Vorotnyuk (Eds.): Theorizing Security in the Eastern European Neighbourhood pp. 60-81. Bratislava - Kyiv: STRATPOL.

KLITOU, D., 2014: Privacy, Liberty and Security. Pp. 13-25. In: Klitou D, (Ed.) Privacy-Invading Technologies and Privacy by Design. Berlin: Springer and TMC Asser Press.

MARX, G. T., 2003. A Tack in the Shoe: Neutralizing and Resisting the New Surveillance. Journal of Social Issues 59, No. 2, pp. 369-390.

PAVONE, V. - GOMEZ, S. E. - JAQUET-CHIFELLE, D. O., 2016: A Systemic Approach to Security: Beyond the Tradeoff between Security and Liberty. Democracy and Security 12, No. 4, pp. 225-246. DOI: 10.1080/17419166.2016.1217776.

RAMCHARAN, B., 2004: Human Rights and Human Security. Disarmament Forum Strengthening Disarmament and Security, No. 1, pp. 39-48.

REHM, P., 2016: Risk Inequality and Welfare States: Social Policy Preferences, Development, and Dynamics. Cambridge: Cambridge University Press.

RYKKJA, L. H. - LAEGREID, P. - FIMREITE, A. L., 2011: Attitudes Toward Antiterror Measures: The Role of Trust, Political Orientation, and Civil Liberties Support. Critical Studies on Terrorism 4, No. 2, pp. 219-237.

SAWARD, M., 2006: The State and Civil Liberties in the Post 9-11 World. In: Dunleavy, P. et al. (eds.): Developments in British Politics, Volume 8. UK: Palgrave Macmillan: pp. 212-230.

SCHEURMAN, W. E., 2016: Digital Disobedience and the Law. New Political Science 38, No. 3, pp. 299-314.

STANDARD EUROBAROMETER 87. Wave EB87.3. Spring 2017. http://ec.europa.eu/commfrontoffice/publicopinion

WAGNER, A. - KNEIP S., 2015: Demokratische Gefahr für die Demokratie? In: W. Merkel (ed.): Demokratie und Krise. Zum schwierigen Verhältnis von Theorie und Empirie. Springer Fachmedien Wiesbaden, pp. 339-372. 